\title{
Atypical Polyagglutination Associated with an Acquired B Antigen
}

\author{
M. L. Beck, R. H. Walker, and H. A. Oberman \\ From the Department of Pathology, The University of Michigan, Ann Arbor, \\ and the Department of Pathology, William Beaumont Hospital, Royal Oak, Michigan
}

\begin{abstract}
The finding of an acquired $B$ antigen, together with polyagglutination, in an elderly man led to studies indicating adsorption of bacterial material as the likely cause of both of these red blood cell anomalies. The various causes of polyagglutination are discussed. Based upon the differential characteristics of each type, a classification of polyagglutination is proposed.
\end{abstract}

Polyagglutination denotes the agglutination of red blood cells by most normal adult sera, but not by the sera of newborn infants. This abnormality has been noted most frequently in association with either bacterial contamination in vitro or bacterial infection in vivo. When observed in vivo, the phenomenon usually is temporary, although orcasionally it has persisted for months ${ }^{25}$ or even for several years. ${ }^{14}$

Red blood cells treated with neuraminidase provide a model of polyagglutination. This enzyme splits $\mathbf{N}$-acetyl-neuraminic acid from sialo-mucoproteins ${ }^{16}$ exposing structures capable of reacting with the anti$T$ agglutinin of normal serum, and this, or a very similar mechanism, probably is responsible for most cases of $T$-activation in vivo. In addition, the polyagglutinable state in vivo occasionally results from causes other than classical $T$-activation, a condition termed "atypical" polyagglutination. 5, 9, 13, 14, 16

This report describes a further case of atypical polyagglutination; however, in this instance it is associated with an acquired $B$ antigen.

Received for publication February 26, 1971; accepted June 8, 1971.

\section{Materials and Methods}

Serum was obtained from clotted blood samples and stored frozen until tested. Red blood cell suspensions were prepared from whole blood or EDTA anticoagulated samples as two to five per cent suspensions in saline.

$T$-activating enzyme, T-active red blood cells and anti-T lectin were prepared as previously described. ${ }^{1}$

Adsorption was performed by incubating equal volumes of packed cells and serum for one hour at 4 C. Group AB sera were autoadsorbed overnight at $4 \mathrm{C}$.

Eluates were prepared by the heat method of Landsteiner and Miller. 17

2-mercapto-ethanol (2-ME) denaturation was carried out by incubating equal volumes of serum and of $0.1 \mathrm{M} \mathrm{2-ME}$ at $37 \mathrm{C}$ for two hours. The serum was cleared of 2-ME by dialysis against running water for 45 minutes followed by two changes of $500 \mathrm{ml}$ volumes of physiologic saline solution for $\mathbf{3 0}$ minutes each.

Concentration of serum was accomplished with Carbowax." Two ml of serum were dialysed against Carbowax until the volume had been reduced to $0.5 \mathrm{ml}$.

Saliva specimens were placed in a boiling water bath for 10 minutes immediately after collection, centrifuged, and stored frozen.

Neutralization tests were performed by adding two volumes of serum or eluate to one volume of saliva. One volume of cells was added after a five-minute neutralization period.

Secretor status was determined by adding an equal volume of diluted antiserum to saliva. One volume of appropriate test cells was added after a 30-minute neutralization period. Results were read following incubation at room temperature for 30 minutes.

\footnotetext{
- Obtained from Mann Research, N. Y.
} 
TABLE 1. Initial Reactions of Patient's Blood

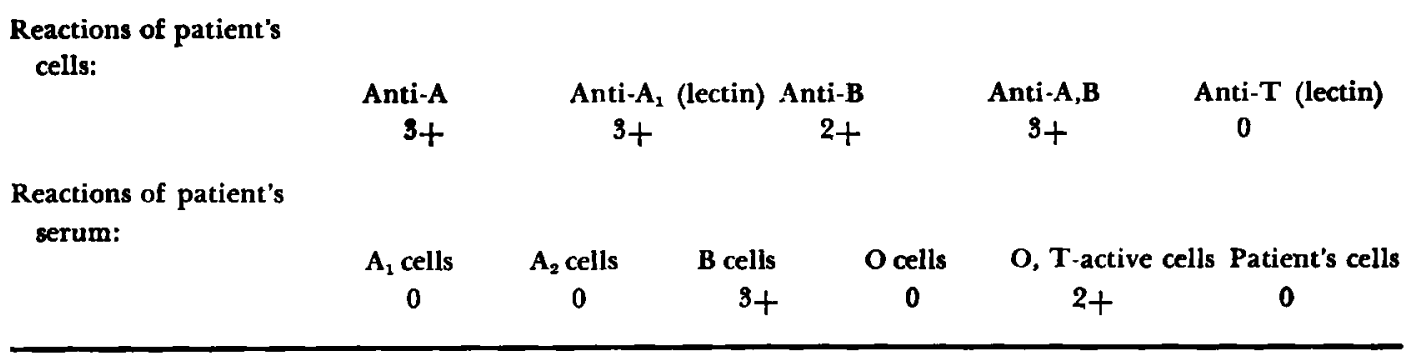

\section{Case Report}

A 94-year-old Caucasian man was admitted to the hospital in August 1970, with an acute urinary tract infection. He also had prostatic hyperplasia and mild diabetes mellitus. An organism belonging to the Klebsiella-enterobacter group was isolated from his urine. He was treated with catheter drainage and antibiotics, and was scheduled for a transurethral resection of the prostate.

Preoperative blood typing results were anomalous. His cells reacted with anti-A and weakly with anti-B; however, his serum agglutinated only type B cells. Pretreatment of the patient's cells with ficin and bromelin did not modify their reactivity with anti-B. Examination of a specimen two months later revealed similar, but weaker, findings. At that time the patient was much improved, although he continued to manifest asymptomatic bacteriuria. He had been hospitalized elsewhere in November 1969, and on that occasion he was found to be type $A$ and was transfused with two units of type $A$ blood without incident.

\section{Serologic Studies}

The finding of a weak $B$ antigen together with anti-B in the serum of a patient previously found to be type A suggested two possibilities: an acquired $B$ antigen or polyagglutinability of erythrocytes. Accordingly, the patient's cells were tested with standard ABO typing reagents and with Arachis hypogoea, a lectin specific for $T$ activated red blood cells. ${ }^{6}$ The results of these tests are given in Table 1. The direct antiglobulin test was negative. The patient's serum was tested with a variety of cells and found to contain anti-B and anti$T$. His saliva contained $A$ and $H$ substances. The presence of anti- $T$ in the serum, and the negative result when his

TABLE 2. Reactions of Patient's Cells with 12 Type $A$ Sera before and after Addition of Type B Secretor Saliva

\begin{tabular}{|c|c|c|c|c|c|c|c|c|c|c|c|c|}
\hline & \multicolumn{12}{|c|}{ Serum Specimen } \\
\hline & 1 & 2 & 3 & 4 & 5 & 6 & 7 & 8 & 9 & 10 & 11 & 12 \\
\hline \multicolumn{13}{|c|}{ Before Addition of B Secretor Saliva } \\
\hline Patient's cells & $3+$ & $2+$ & $3+$ & $4+$ & $4+$ & 0 & $3+$ & $4+$ & 0 & 0 & 0 & $3+$ \\
\hline Control type B cells & $4+$ & $4+$ & $4+$ & $4+$ & $3+$ & $3+$ & $3+$ & $4+$ & $2+$ & $4+$ & $4+$ & $4+$ \\
\hline Control type $O$ cells & $\mathbf{0}$ & 0 & $\mathbf{0}$ & 0 & $\mathbf{0}$ & $\mathbf{0}$ & 0 & $\mathbf{0}$ & $\mathbf{0}$ & $\mathbf{0}$ & $\mathbf{0}$ & 0 \\
\hline \multicolumn{13}{|c|}{ After Addition of B Secretor Saliva } \\
\hline Patient's cells & $1+$ & 0 & $1+$ & $4+$ & $1+$ & $\mathbf{0}$ & 0 & \pm & 0 & $\mathbf{0}$ & $\mathbf{0}$ & $\mathbf{0}$ \\
\hline Control type B cells & $\mathbf{0}$ & 0 & $\mathbf{0}$ & 0 & $\mathbf{0}$ & 0 & 0 & $\mathbf{0}$ & $\mathbf{0}$ & $\mathbf{0}$ & $\mathbf{0}$ & 0 \\
\hline Control type $O$ cells & 0 & 0 & $\mathbf{0}$ & 0 & $\mathbf{0}$ & $\mathbf{0}$ & 0 & $\mathbf{0}$ & 0 & 0 & 0 & 0 \\
\hline
\end{tabular}

Conditions of test: One hour at $4 \mathrm{C}$ followed by centrifugation. 
TABLE 3. Reactions at OC for Two Hours of Patient's Erythrocytes with Normal Type AB Sera

\begin{tabular}{llllllllllllll}
\hline & \multicolumn{11}{c}{} & \multicolumn{11}{c}{ Serum Specimen } \\
\cline { 2 - 13 } & 1 & 2 & 3 & $4 *$ & 5 & 6 & 7 & $8 *$ & 9 & 10 & 11 & 12 \\
\hline Patient's cells & $2+$ & $3+$ & $4+$ & $3+$ & $3+$ & $4+$ & $3+$ & $3+$ & $2+$ & $2+$ & $3+$ & $3+$ \\
$A_{1}$ cells & 0 & 0 & 0 & \pm & 0 & 0 & 0 & \pm & 0 & 0 & 0 & 0 \\
B cells & 0 & 0 & 0 & $1+$ & 0 & 0 & 0 & \pm & 0 & 0 & 0 & 0 \\
O cells & 0 & 0 & 0 & $1+$ & 0 & 0 & 0 & $1+$ & 0 & 0 & 0 & 0 \\
O, T-active cells & $1+$ & $2+$ & 0 & $2+$ & 0 & $2+$ & $2+$ & $2+$ & $3+$ & 0 & $1+$ & $2+$ \\
Oi cells (adult) & 0 & 0 & 0 & 0 & 0 & 0 & 0 & 0 & 0 & 0 & 0 & 0 \\
O cord blood cells & 0 & 0 & 0 & 0 & 0 & 0 & 0 & 0 & 0 & 0 & 0 & 0 \\
\hline
\end{tabular}

- The reactions given by sera 4 and 8 are considered to be due to anti-I.

cells were tested with Arachis hypogoea lectin, indicated that $\mathrm{T}$-activation of the patient's cells was not the cause of the anomalous ABO typing.

Additional tests were performed with several type A sera known to be free of irregular antibodies (Table 2). The tests were repeated after the addition of type B secretor saliva to these sera (Table 2).

The addition of B-substance was inhibitory and supported the contention that this patient had acquired a B-like antigen on his red blood cells. This was confirmed by demonstrating anti-B in eluates from these cells following their exposure to a commercial anti-B typing reagent. However, addition of type $B$ secretor saliva to the eluate did not completely inhibit its reactivity with the patient's cells, although activity with normal B cells was abolished. Similar results were seen when the patient's cells were tested with type A sera neutralized with B-substance (Table 2) .

The persistence of agglutination of the patient's cells, both with normal type A sera and with anti-B reagents neutralized with B-substance, suggested reactivity of the cells with a high frequency agglutinin. Since this agglutinin also should be present in normal type $\mathrm{AB}$ serum, the patient's cells were tested with a series of type $A B$ sera for two hours at $0 \mathrm{C}$ in an ice bath (Table 3). These sera had been adsorbed previously to remove cold auto-antibodies. All of these sera agglutinated the patient's cells and, with the exception of two, failed to agglutinate normal type $B$ cells. Removal of anti-T agglutinins by adsorption with $T$-active type $O$ cells did not remove the agglutinin directed against the patient's cells. However, this agglutinin was inactivated by treating the serum with 2mercapto-ethanol, a characteristic of IgM.

An aliquot of the cells was frozen in glycerol at $-20 \mathrm{C}$ to permit comparison of their polyagglutinable properties with future samples.

The acquired $B$ antigen was detectable in a blood specimen examined two months after hospitalization, although reactions with anti-B sera were much weaker than those first seen. At that time the patient manifested asymptomatic bacteriuria. Agglutination of the patient's cells at $4 \mathrm{C}$ with type A serum was barely visible macroscopically and gave a mixed field appearance microscopically. Following exposure to anti-B typing reagent, an eluate from the patient's cells yielded anti-B. The patient's red blood cells reacted weakly with ten of 12 type $A B$ sera although strength of reactivity was improved when the sera were concentrated four-fold with Carbowax. The concentrated sera did not react with normal cells.

The reactivity of these cells was com- 
pared with that of cells collected two months earlier. These frozen-preserved cells were recovered by dialysis. The acquired-B antigen continued to be detectable in the first specimen, but the cells no longer were agglutinated by the type AB sera and serum concentrates with which they had originally reacted. Apparently, storage of the cells in glycerol at $-20 \mathrm{C}$ had destroyed the receptors responsible for the polyagglutinability. These frozen-preserved cells also had lost their ability to adsorb and eluate the agglutinin. Loss of polyagglutinability was also demonstrated in the more recent specimen after overnight storage in glycerol at $-20 \mathrm{C}$.

\section{Discussion}

The serologic reactivity of the blood of this elderly man, previously found to be type A, permits the conclusion that his red blood cells temporarily had acquired a Blike antigen as well as polyagglutinable properties.

Apparent change of a patient's blood type from $A$ to $A B$ has been observed most often in association with intra-abdominal malignancy, infection and intestinal obstruction. $2,7,8,19,26$ The present patient had a urinary tract infection. It is reasonable to assume a common cause of the polyagglutinability and the change in ABO specificity, since both apparently were acquired during the same infection. Furthermore, the strength of both acquired characteristics fluctuated with the severity of the infection.

The mechanism by which the B-like antigen is acquired by red blood cells is unclear. Springer and Ansell ${ }^{23}$ suggested that this may occur through passive adsorption of bacterial lipopolysaccharide. To support this contention, Springer ${ }^{24}$ reported that lipopolysaccharide from certain strains of $E$. coli $\left(E\right.$. coli $\mathrm{O}_{86}$ ) had terminal galactosyl groups which conferred blood type B specificity to human red blood cells in vitro. In contrast, Marsh ${ }^{19}$ favors enzymatic modification of the red blood cells as the cause of the reaction. This is based on his observation that bacterial enzymes could confer a B-like antigen to red blood cells, as well as producing red blood cell $\mathrm{T}$-activation.

The type of polyagglutinability manifested by this patient's red blood cells is a more intriguing problem than is the acquired $B$ antigen. The absence of $T$-activation of the red blood cells is not unique, for it is well established that polyagglutination can occur by other means. Such "atypical" polyagglutination has been related to Tn-activation of the red blood cell, and five such cases have been reported. $5,13,14,15,20$

Both $T$ - and Tn-activation result from enzymatic activity on the red blood cell surface; however, it is likely that different enzymes are involved. Both $\mathrm{T}$ - and $\mathrm{Tn}$ activated cells manifest reduced sialic acid levels.5, 16, 27 This is associated with loss of the MN antigens in the fully $\mathrm{T}$-activated cell, although this has not been observed in Tn-activation. This suggests that, although sialic acid is lost in each instance, different substrates are modified.

This patient's polyagglutinability disappeared following storage at $-20 \mathrm{C}$. Furthermore, in contrast to $\mathbf{T}$-activated erythrocytes, this patient's cells failed to react with IgG $\mathbf{R} h$ antisera. It has been demonstrated in this laboratory that both $T$ - and Tn-activated cells retain their polyagglutinability for many months at -20 C. 4 Therefore, this suggests that passive adsorption, rather than an enzymatic change, is the most likely cause of the patient's reaction.

The instability of this patient's red blood cell polyagglutinability constitutes an important differential feature. Such instability of polyagglutination also was observed in patients reported by Garratty ${ }^{12}$ and Stratton.25 Garratty's patient was 
analogous to ours, in that an acquired B antigen was present.

Another report of unusual polyagglutination is that of Freiesleben et al.,11 who described permanent mixed field polyagglutination in a blood donor, with no demonstrable red blood cell $\mathrm{T}$-activation. Cazal $^{9}$ reported polyagglutination, in the absence of $\mathrm{T}$-activation, in three members of the same family. We are also aware of a patient who had red blood cell polyagglutinability due to Tn-activation with an associated acquired $\mathrm{A}$ antigen. ${ }^{5}$

The above reports indicate that at least four types of red blood cell polyagglutination can be recognized, the characteristics of each being sufficiently distinct to permit the following classification:

\section{Type I. Typical T-activation}

These red blood cells manifest transient polyagglutination associated with bacterial infection.1, 10, 18, 21, 22 The erythrocytes are reactive with Arachis lectins and are deficient in $\mathrm{Sp}_{1}$ antigen. ${ }^{3}$ The strength of reactivity of the $\mathrm{MN}$ antigens is diminished in direct proportion to the degree of $T$. activation. ${ }^{4}$ These findings indicate en zymatic changes in vivo. The polyagglutinability is resistant to freezing in glycerol, and the anti-T agglutinins, found in all normal adult sera, are absent.

Type II. Atypical Polyagglutination due to $T n$

Red blood cells polyagglutinable due to the presence of the $T n$ antigen are not agglutinated by Arachis lectins; however, those cells lacking the $A_{1}$ antigen continue to react with Dolichos lectins. The polyagglutination appears to be a prolonged, if not a permanent feature of the patient, as a result of enzymatic activity in vivo. The majority of patients with this phenomenon have had either anemia, leukopenia or thrombocytopenia.5, 13-15, 20
Type III. Polyagglutination with Acquired $B$ Antigen

This type of erythrocyte polyagglutinability, manifested by the patient in this report, appears to be associated with an acquired $B$ antigen. Both our patient and the one described by Garratty ${ }^{12}$ had a history of bacterial infection coincident with the red blood cell polyagglutinability, and only the acquired $B$ antigen was demonstrable after the red blood cells had been stored in glycerol at $-20 \mathrm{C}$. Type III polyagglutinable cells are not agglutinated by Arachis or Dolichos lectins. The agglutinin for the acquired antigen appears to be a regular feature of normal sera and is distinct from anti-T and anti-Tn. The expression of the $\mathrm{MN}$ antigens is normal and we suspect that the $S \mathrm{P}_{1}$ antigen is unaffected. In contrast to other types, Type III polyagglutinability probably is the result of adsorption in vivo of the antigenic material of bacterial origin.

\section{Type IV. Inheritable Polyagglutination}

This red blood cell anomaly is typified by the Cad family described by Cazal et al. 9 The antigen is an inheritable surface receptor reactive with most human sera.

\section{References}

1. Beck, M. L.: The technical problem of T-activation. Transfusion 8: 109, 1968.

2. —, J. Dixon, and H. A. Oberman: A further example of an acquired $B$ antigen. J. Med. Lab. Technol. 27: 528, 1970.

3. - - and W. L. Marsh: Red cell $S p_{1}$ antigen change associated with in vivo polyagglutinability. Vox Sang. 19: 91, 1970.

4. —_ Unpublished data.

5. Berman, H. J., J. Smarto, C. Hanson, P. D. Issitt, W. L. Marsh, and L. Jensen: $A$ case of Tn-activation with an acquired A-like antigen. In preparation.

6. Bird, G. W. G.: Anti-T in peanuts. Vox Sang. 9: 748, 1964. 
7. Burns, W., W. Friend, and J. Scudder: Development of an acquired blood group antigen in surgical patients with peritonitis due to Escherichia coli. Surg. Gynec. Obstet. 120: 757, 1965.

8. Cameron, C., F. Graham, I. Dunsford, G. Sickles, C. R. MacPherson, A. Cahan, R. Sanger, and R. R. Race: Acquisition of a B-like antigen by red blood cells. Brit. Med. J. 2: 29, 1959.

9. Cazal, P., M. Monis, J. Caubel, and J. Brives: Polyagglutinabilite hereditaire dominate: Antigene prive (Cad) correspondant a un anticorps public et a une lectine de Dolichos biflorus. Rev. Franc. Transfusion 11: 209, 1968.

10. Chorpenning, F. W., and J. C. Hayes: Occurrence of the Thomsen-Friedenreich phenomenon in vivo. Vox Sang. 4: 210, 1959.

11. Freiesleben, E., K. G. Jensen, and E. E. Knudsen: Permanent mixed field polyagglutinability. Proc. VIIIth Cong. Europ. Soc. Haemat., Vienna, 1961, 11: 506. (Karger, Basel, 1962).

12. Garratty, G., E. Willbanks, and L. D. Petz: An acquired $B$ antigen associated with proteus vulgaris infection. Vox Sang. In press.

13. Gunson, H. H., F. Stratton and G. W. Mul. lard: An example of poiyagglutinability due to the Tn antigen. Brit. J. Haemat. 18: 309 , 1970.

14. van der Hart, M., M. Moes, J. J. van Loghem, J. H. J. Enneking, and C. H. W. Leeksma: A second example of red cell polyagglutinability caused by the $\mathrm{Tn}$ antigen. Vox Sang. 6: 358, 1961.

15. Haynes, C. R., I. Dorner, G. I. Leonard, W. R. Arrowsmith, and H. Chaplin, Jr.: Persistent polyagglutinability in vivo unrelated to T-antigen activation. Transfusion 10: 43, 1970.

16. Klenk, E., and G. Uhlenbruck: Uber ein neuraminsäurehaltiges Mucoprotein aus Rindererythrocytenstroma. Z. Physiol. Chem. 311: 227, 1958.

17. Landsteiner, K., and C. P. Miller: Serological studies on the blood of primates: II. The blood groups in anthropoid apes. J. Exp. Med. 42: 853, 1925.

18. van Loghem, J. J., M. van der Hart, and M. E.
Land: Polyagglutinability of red cells as a cause of severe haemolytic transfusion reaction. Vox Sang. 5: 125, 1955.

19. Marsh, W. L., W. J. Jenkins, and W. W. Walther: Pseudo-B: an acquired group antigen. Brit. Med. J. 2: 63, 1959.

20. Moreau, R., J. Dausset, J. Bernard, and J. Moullec: Anémie hémolytique acquisé avec polyagglutinabilité des hematies par un nouveau facteur present dans le serum humain normal (anti-Tn). Bull. Soc. Med. Hop. Paris 73: 569, 1957.

21. Reepmaker, J.: The relation between polyagglutinability of erythrocytes in vivo and the Huebner-Thomsen-Friedenreich phenomenon. J. Clin. Path. 5: 266, 1952.

22. Rickard, K. A., R. J. Robinson, and S. M. Worlledge: Acute acquired haemolytic anemia associated with polyagglutination. Arch. Dis. Child. 44: 102, 1969.

23. Springer, G. F., and N. J. Ansell: Acquisition of blood group B-like antigens by human $A$ and $O$ erythrocytes. Fed. Proc. Amer. Soc. Exp. Biol. 19: 70, 1960.

24. Springer, G. F.: Beziehungen zwischen Mikroben und blutgruppenaktiven Substanzen. Angew. Chem. (Eng.) 78: 967, 1966.

25. Stratton, F.: Polyagglutinability of red cells. Vox Sang. 4: 58, 1954.

26. - $\longrightarrow$ and P. H. Renton: Acquisition of B-like antigen. Brit. Med. J. 2: 224, 1959.

27. Uhlenbruck, G., G. I. Pardoe, and G W. G. Bird: On the specificity of lectins with a broad agglutination spectrum. II. Studies on the nature of the $T$ antigen and the specific receptors for Arachis hypogoea lectin. Z. Immunitaetsforsch. 138:423, 1969.

Malcolm L. Beck, F.I.M.L.T., Research Technologist, Blood Bank Section, Department of Pathology, University of Michigan Medical Center, 1335 E. Catherine Street, Ann Arbor, Michigan 48104.

Richard H. Walker, M.D., Department of Pathology, William Beaumont Hospital, Royal Oak, Michigan.

Harold A. Oberman, M.D., Professor of Pathology and Medical Director of Blood Bank, University of Michigan Medical Center, Ann Arbor, Michigan 48104. (Correspondence) 